\title{
GMR
}

\section{Purification, characterization, and heterologous expression of an antifungal protein from the endophytic Bacillus subtilis strain Em7 and its activity against Sclerotinia sclerotiorum}

\author{
N.N. Wang, X.N. Gao, X. Yan, Z.P. Li, Z.S. Kang, L.L. Huang and Q.M. Han \\ State Key Laboratory of Crop Stress Biology for Arid Areas and College of Plant \\ Protection, Northwest A\&F University, Yangling, Shaanxi, China \\ Corresponding author: L.L. Huang \\ E-mail: huanglili1@hotmail.com
}

Genet. Mol. Res. 14 (4): 15488-15504 (2015)

Received August 10, 2015

Accepted October 2, 2015

Published November 30, 2015

DOI http://dx.doi.org/10.4238/2015.November.30.27

\begin{abstract}
An antifungal protein exhibiting a high activity against Sclerotinia sclerotiorum in vivo was purified by ammonium sulfate precipitation, hydrophobic chromatography, and gel filtration chromatography from the culture filtrate of the endophytic Bacillus subtilis strain Em7. The protein was characterized as a $\beta-1,3-1,4-$ glucanase according to amino acid analysis, and showed excellent properties in thermal stability and acid resistance. At the same time, the antifungal protein was cloned and heterologously expressed in Escherichia coli BL21. The recombinant protein was purified and showed similar enzymatic properties to the native protein, exhibiting strong inhibitory activity against $S$. sclerotiorum. This shows that the $\beta-1,3-1,4-$ glucanase may play a very important role in $B$. subtilis Em7 biocontrol function. In addition, many physiochemical properties of the native and purified recombinant protein were compared, including the effect of $\mathrm{pH}$, temperature, metal cations, substrate specificity, and kinetic parameters. All parameters were similar between the native and recombinant pu-
\end{abstract}


rified protein, indicating that the purified recombinant protein has potential for industrial applications.

Key words: Antifungal activity; Heterologous expression; Bacillus subtilis; $\beta$-1,3-1,4-glucanase; Sclerotinia sclerotiorum

\section{INTRODUCTION}

Sclerotinia sclerotiorum is a widespread soil-borne plant pathogen with a wide host range (Bol and Hall, 1994) and it can cause serious crop diseases such as sclerotinia stem rot of canola. In China, sclerotinia stem rot had a serious impact on yield and quality of rapeseed oil and it has been reported that the reduced yield caused by sclerotinia stem rot is anywhere from 10 to $80 \%$ (Oilcrop Research Institute, Chinese Academy of Sciences, 1975). At present, control of canola sclerotinia stem rot mainly relies on the use of long field rotations and fungicidal sprays. However, controlling sclerotinia by rotation is not very effective as the pathogen persists as sclerotia (survival structures) in soil for long periods of time. The use of fungicidal agents, such as carbendazim (MBC) and benzimidazole, to control the disease has had some success but is limited due to the increase of resistant pathogens (Zhang et al., 2003).

Biological control of plant diseases with antagonistic bacteria is a promising strategy and has attracted considerable interest (Mizumoto and Sawa, 2007). This strategy is environmentally friendly with no chemical residue and no developed resistance so it meets the demand for food safety and environmental protection and solves the resistance problems from the long-term use of chemical pesticides. Some natural antagonistic bacteria, such as Pseudomonas (Haas and Défago, 2005) and Bacillus subtilis, have garnered much attention in their exploitation as biological agents and have also been shown to control fungal infections. However, their biological effect in fields was not consistent and they were not tested in large-scale fields, due to the fact that they are more susceptible to biotic and abiotic factors (Tsuda et al., 2001).

For these reasons, endophytic bacteria, a class of microorganisms that mainly reside in the vascular space and internal tissue cells of the plant and do not cause disease in plants, has received more attention. Endophytic bacteria use plants as a stable living space and are less susceptible to environmental conditions so they can grow independently and are easy to transmit. In addition, Bacillus strains can form spores, which is more convenient for preparation and storage as biocontrol agents. These advantages make endophytic Bacillus strains a potential biocontrol microbe for controlling plant diseases. A number of endophytic wild-type B. subtilis strains showing biocontrol potential have been isolated and examined (Khardenavis et al., 2007). The biological control activity of endophytic $B$. subtilis mainly relies on three main traits (Cawoy, 2015). The first is to form a stable colony and gain high ecological fitness. This is a prerequisite because endophytic bacteria need to be the preferential colonizers in plants in order to act as a biocontrol agent; otherwise, they will compete for space and nutrients with the rhizosphere microbiome. The second is the variety of strong antagonistic active substances against plant pathogens secreted by endophytic $B$. subtilis. The third is induced systemic resistance (Berendsen et al., 2012), which can induce an immune response in plant tissue so that the host plants are less susceptible to subsequent infection. The secretion of antagonistic substances is an important mechanism for endophytic $B$. subtilis in the biological control process, and the biological effect depends largely on the variety and amount of the antagonistic substances produced by biological microorganisms. The antifungal substances produced by B. subtilis are divided into three categories: antibiotics (Katz and Demain, 1977) such 
as mycobacillins (Majumdar and Bose, 1958; Sengupta et al., 1971), iturins (Isogai et al., 1982), bacillomycins (Peypoux et al., 1981, 1984), surfactins (Kluge et al., 1988), mycosubtilins (Peypoux et al., 1986; Besson and Michel, 1990), fungistatins (Korzybski et al., 2013), subsporins (Ebata et al., 1969), and rhizocticins (Kugler et al., 1990); cell wall degrading enzymes (Sadfi et al., 2001); and antifungal proteins (Liu et al., 2007). Many new antifungal substances are continually being identified. Therefore, it seems that there is a high potential to screen novel, highly active antifungal substances from the strains of the endophyte $B$. subtilis, which potentially have great prospects to be exploited as economical biological control agents.

Our preliminary results indicate that the endophytic B. subtilis strain Em7 showed high antifungal activity and could control oilseed rape stem rot in vivo and in the field (Gao et al., 2014). The purpose of this study was to purify and characterize the main antifungal protein produced by $B$. subtilis Em7 in order to study its antifungal mechanisms against the common plant fungus S. sclerotiorum.

\section{MATERIAL AND METHODS}

\section{Strains, plasmids, chemicals, and reagents}

The endophytic $B$. subtilis Em7 strain was isolated from wheat roots and collected by our lab. The bacterial strain was grown using Luria-Bertani medium (LB) at $28^{\circ} \mathrm{C}$ for $16-20 \mathrm{~h}$. The plant pathogen S. sclerotiorum (obtained from the Department of Plant Pathology of Northwest A\&F University, Shaanxi, China) was grown on potato dextrose agar (PDA) at $25^{\circ} \mathrm{C}$ for 3 days. The recombinant plasmid was amplified using Escherichia coli JM109 and E. coli BL21 (DE3) at $37^{\circ} \mathrm{C}$ on LB plates by adding appropriate antibiotics used for gene expression assays. The other chemicals and reagents used were of analytical grade. The pMD20-T vector was used for gene cloning (Generay Biotechnology, Shanghai, China) and pET32a (+) vector (Novagen, Beijing, China) was used for gene expression. Other biochemical reagents and kits were obtained from Invitrogen Life Technologies (Shanghai, China). Various enzyme substrates were obtained from Sigma-Aldrich (Shanghai, China). Enzyme activity was measured using the dinitrosalicylic (DNS) method (Bailey, 1988). The protein concentration was assayed by the Bradford method (Bradford, 1976).

\section{Purification and characterization of an antifungal protein from B. subtilis Em7}

\section{Crude protein extraction and antifungal activity detection}

B. subtilis Em7 was pre-cultured in LB broth at $28^{\circ} \mathrm{C}$ for $14-16 \mathrm{~h}$. Then, $3 \mathrm{~mL}$ pre-culture was inoculated into $200 \mathrm{~mL} \mathrm{LB}$ liquid medium, $\mathrm{pH} 7.0$, at $28^{\circ} \mathrm{C}$ for $40 \mathrm{~h}$ with shaking at $150 \mathrm{rpm}$, and the supernatant was collected after centrifugation $\left(10,621 \mathrm{~g}, 4^{\circ} \mathrm{C}, 20 \mathrm{~min}\right)$. Solid ammonium sulfate was slowly added to the supernatant to $90 \%$ relative saturation, and the ammonium sulfate gradients were $0-30,30-40,40-50,50-60,60-70,70-80$, and 80-90\%. After incubation at $4^{\circ} \mathrm{C}$ overnight and centrifugation $\left(15,294 \mathrm{~g}, 4^{\circ} \mathrm{C}\right.$ for $\left.30 \mathrm{~min}\right)$, the precipitate was dissolved in 10 $\mathrm{mL}$ phosphate buffer $(20 \mathrm{mM}, \mathrm{pH} 7.0)$ and dialyzed to remove residual ammonium sulfate with deionized water. The crude protein extracts were lyophilized.

One microgram of crude protein was solubilized in $10 \mathrm{~mL}$ phosphate buffer $(20 \mathrm{mM}, \mathrm{pH}$ 7.0) and its antifungal activity against $S$. sclerotiorum was determined using the oxford cup method. Briefly, a sterile oxford cup with $200 \mu \mathrm{L}$ crude protein solution was placed in the center of a PDA 
plate, and two 5-mm diameter mycelium-grown agar disks were inoculated on both sides of the same plate. The antifungal effect of the crude protein at different dilutions was determined after the PDA plate was cultured at $25^{\circ} \mathrm{C}$ for 3 days. The experiment was done in duplicate and was repeated three times for each treatment.

\section{Hydrophobic chromatography}

Fractions of the crude protein extract exhibiting antifungal activity were solubilized in phosphate buffer $\left[20 \mathrm{mM}, \mathrm{pH} 7.0\right.$, containing $\left.1 \mathrm{M}\left(\mathrm{NH}_{4}\right)_{2} \mathrm{SO}_{4}\right]$ and filter sterilized after centrifugation at $10,000 \mathrm{rpm}$ at $4^{\circ} \mathrm{C}$ for $10 \mathrm{~min}$. The filtrate was then loaded onto a phenyl-Sepharose 6 fast flow prepacked column $(0.7 \times 2.5 \mathrm{~cm}$; Amersham Biosciences, Beijing, China) and eluted with a stepwise phosphate buffer gradient [ $20 \mathrm{mM}, \mathrm{pH} 7.0$, containing between $0-0.5 \mathrm{M}\left(\mathrm{NH}_{4}\right)_{2} \mathrm{SO}_{4}$ ] at a flow rate of $0.5 \mathrm{~mL} /$ min. Different fractions of eluted proteins were collected and their antifungal activities were detected using the oxford cup method. Active fractions were dialyzed with deionized water and lyophilized.

\section{Gel filtration chromatography}

Fractions from hydrophobic chromatography showing antifungal activity were solubilized in phosphate buffer $(50 \mathrm{mM}, \mathrm{pH} 7.0$, containing $0.15 \mathrm{M} \mathrm{NaCl})$ and filter sterilized. This was applied to a Superdex100 10/300GL (1.0 x $100 \mathrm{~cm}$; Amersham Biosciences) and eluted with a stepwise sodium chloride gradient (containing $0-0.5 \mathrm{M} \mathrm{NaCl}$ ) at $0.5 \mathrm{~mL} / \mathrm{min}$. Fractions showing antifungal activity were dialysed using deionized water and lyophilized.

\section{Polyacrylamide gel electrophoresis (PAGE) and protein identification}

PAGE was used to detect the proteins collected from hydrophobic chromatography and gel filtration chromatography. Fractions showing antifungal activity from gel filtration chromatography were solubilized in phosphate buffer, $\mathrm{pH}$ 7.0, and detected by PAGE. After PAGE analysis, the protein band was excised and sent to the National Center of Biomedical Analysis (NCBA, China) for identification by mass spectrometry. Sequence homology was analyzed using NCBI BLAST.

\section{Heterologous expression and characterization of the antifungal protein from B. subtilis Em7 in Escherichia coli BL21}

\section{Cloning and sequencing of the antifungal protein gene from B. subtilis Em7}

A pair of primers, designed as QF (5'-CGCGGATCCATGCCTTATCTGAAACGAGTG-3')

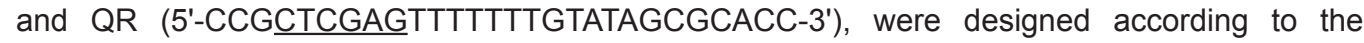
DNA sequence of the antifungal protein identified, and the underlined bases are BamHI and Xhol recognition sites, respectively. Genomic DNA of $B$. subtilis Em7 was prepared according to the manufacturer protocol of the Genome DNA Extraction Kit (TIANGEN, Beijing, China). The antifungal protein gene was amplified by polymerase chain reaction (PCR) using genomic DNA of Em7 as the template and QF/QR as the primers. The amplified product was purified using a PCR purification kit (Omega, Guangzhou, China) and ligated into the pMD20-T vector. The ligation mixture was transformed into E. coli JM109 competent cells by the heat-shock method. Positive 
clones were screened on LB plates containing ampicillin $(100 \mu \mathrm{g} / \mathrm{mL})$. The corresponding plasmids were extracted using a plasmid extraction kit (Omega) and sequenced by Beijing AuGCT DNASYN Biotechnology Co. (Beijing, China). Nucleotide sequence and corresponding amino acid sequences were analyzed using BLAST (NCBI database) and ExPASy Proteomics tools.

\section{Construction of expression vector}

Plasmids verified by sequencing were subjected to a double-digestion using BamHI (10 $\mathrm{U} / \mathrm{mL}$; Fermentas, Beijing, China) and Xhol (10 U/mL; Fermentas). This fragment (containing the antifungal protein gene) was purified and ligated into pET32a (+) using the same enzymes at $16^{\circ} \mathrm{C}$ for $16 \mathrm{~h}$. The ligation mixture was transformed into $E$. coli BL21 (DE3) competent cells by the heatshock method and transformed cells were inoculated on an LB plate containing ampicillin (100 $\mu \mathrm{g} /$ $\mathrm{mL}$ ) and cultured at $37^{\circ} \mathrm{C}$ overnight. The positive recombinants were screened by PCR with the T7 primer. The positive E. coli BL21 (DE3) clones contain an expression vector pET32a (+)-Glu and were renamed as recombinant $E$. coli BL21 (DE3)/pET32a (+)-Glu.

\section{Induction of expression and electrophoresis of recombinant antifungal protein}

The recombinant strain E. coli BL21 (DE3)/pET32a (+)-Glu was inoculated in $5 \mathrm{~mL}$ LB liquid medium (containing $100 \mu \mathrm{g} / \mathrm{mL}$ ampicillin) and cultured at $37^{\circ} \mathrm{C}$ overnight. Then, $1 \mathrm{~mL}$ of this culture was inoculated into $100 \mathrm{~mL}$ LB medium (containing $100 \mu \mathrm{g} / \mathrm{mL}$ ampicillin) and grown at $37^{\circ} \mathrm{C}$ with shaking at $200 \mathrm{rpm}$ until the $\mathrm{OD}_{600}$ value reached $0.4-0.6$. At this time, IPTG was added at a final concentration of $0.5,1,2,4,6$, or $8 \mathrm{mM}$, and the culture was incubated for another $6 \mathrm{~h}$ at $30^{\circ} \mathrm{C}$, shaking at $200 \mathrm{rpm}$. For the controls, E. coli BL21 (DE3)/pET32a strain induced with 1 $\mathrm{mM}$ IPTG and E. coli BL21 (DE3)/pET32a-Glu without IPTG induction were used. The cell pellet from $1-\mathrm{mL}$ culture, obtained by centrifugation at 10,621 $\mathrm{g}$ for $5 \mathrm{~min}$, was resuspended in $100 \mu \mathrm{L}$ $20 \mathrm{mM}$ PBS (140 mM NaCl, $2.7 \mathrm{mM} \mathrm{KCl}, 10 \mathrm{mM} \mathrm{Na}_{2} \mathrm{HPO}_{4}$, and $1.8 \mathrm{mM} \mathrm{KH}_{2} \mathrm{PO}_{4}, \mathrm{pH} 7.3$ ) and 8 $\mu \mathrm{L}$ lysozyme $(50 \mathrm{mg} / \mathrm{L})$ at $37^{\circ} \mathrm{C}$ for $1 \mathrm{~h}$. The mixture was then subjected to $4-5$ freeze-thaw cycles using liquid nitrogen and the supernatant was obtained by centrifugation at 15,294 $\mathrm{g}$ for $10 \mathrm{~min}$. Finally, $15 \mu \mathrm{L}$ of this supernatant was analyzed by sodium dodecyl sulfate (SDS)-PAGE using the Mini-protean III system (Bio-Rad, Beijing, China). Protein bands were visualized by Coomassie brilliant blue R-250 staining.

\section{Purification of the recombinant protein and testing of antifungal activities}

Two hundred milliliters of culture medium inoculated with the recombinant strain $E$. coli BL21 (DE3)/pET32a (+)-Glu had expression induced with $1 \mathrm{mM}$ IPTG following the same procedure as described above. Cells were harvested by centrifugation at $6000 \mathrm{~g}$ for $3 \mathrm{~min}$, resuspended in $50 \mathrm{mM}$ PBS, $\mathrm{pH}$ 6.0, and then disrupted by ultrasonication with $30 \%$ strength and 10 -s intervals for $12 \mathrm{~min}$ (repeated three times). The supernatant was obtained after centrifugation at 38,500 $g$ for $40 \mathrm{~min}$ and filtration with a $0.22-\mu \mathrm{m}$ membrane. Ni-NTA histidine-binding resin (Novagen) was prewashed with 1X Ni-NTA Binding Buffer $(300 \mathrm{mM} \mathrm{NaCl}, 50 \mathrm{mM}$ sodium phosphate, and $10 \mathrm{mM}$ imidazole, $\mathrm{pH}$ 8.0). The supernatant obtained was gently mixed with $1 \mathrm{~mL} 50 \% \mathrm{Ni}-\mathrm{NTA}$ resin (prewashed) and incubated at $4^{\circ} \mathrm{C}$ for $60 \mathrm{~min}$. The mixture was applied to an empty column (Novagen) and the recombinant protein was eluted by a gradient of elution buffer ( $300 \mathrm{mM} \mathrm{NaCl}$, $50 \mathrm{mM}$ sodium phosphate, and 50,100,150, 200, 300, or $500 \mathrm{mM}$ imidazole, pH 8.0) after washing 
with $20 \mathrm{~mL}$ wash buffer ( $300 \mathrm{mM} \mathrm{NaCl}, 50 \mathrm{mM}$ sodium phosphate, $20 \mathrm{mM}$ imidazole, $\mathrm{pH}$ 8.0). Fractions were collected and detected using SDS-PAGE. The resulting protein was dialyzed with deionized water at $4^{\circ} \mathrm{C}$ for $24 \mathrm{~h}$, where the dialysate was replaced 6-8 times during this period.

The antifungal activity of the purified recombinant protein against $S$. sclerotiorum was determined by the oxford cup method. The purified recombinant protein solution was prepared by dissolving $5 \mathrm{mg}$ recombinant protein in $1 \mathrm{~mL}$ PBS solution. Then, $100 \mu \mathrm{L}$ of this recombinant protein solution was added to an oxford cup, with PBS buffer with no recombinant protein used as a control. The test was done in duplicate and repeated three times for each treatment.

\section{Enzyme characterization and comparison of the native antifungal protein from B. subtilis Em7 and the recombinant protein from E. coli BL21}

\section{Effect of pH on enzyme activity}

The optimum $\mathrm{pH}$ of the purified proteins was determined at different $\mathrm{pH}$ values by measuring the enzymatic activity. Phosphate buffer (50 mM, pH 4.4-8.0) and borate buffer (50 $\mathrm{mM}, \mathrm{pH}$ 8.6-10.0) were used for different $\mathrm{pH}$ reaction conditions. The $\mathrm{pH}$ stability of the purified protein was tested by measuring the residual enzyme activity after the protein was incubated under specific $\mathrm{pH}$ conditions at $37^{\circ} \mathrm{C}$ for $2 \mathrm{~h}$.

\section{Effect of temperature on enzyme activity}

The optimum temperature of the purified proteins was determined by measuring the enzyme activity within a temperature range of $25^{\circ}-85^{\circ} \mathrm{C}$. Thermostability was examined by measuring the residual enzyme activity after incubating the enzyme for fixed 30-min intervals at each specified temperature $\left(55^{\circ}, 65^{\circ}, 75^{\circ}\right.$, and $\left.85^{\circ} \mathrm{C}\right)$.

\section{Effect of metal cations on enzyme activity}

In order to test the effects of various metal ions on the antifungal protein, the protein was incubated in phosphate buffer $(50 \mathrm{mM}, \mathrm{pH} 6.4)$ with $5 \mathrm{mM} \mathrm{Co}^{2+}, \mathrm{Fe}^{2+}, \mathrm{Ca}^{2+}, \mathrm{K}^{2+}, \mathrm{Mn}^{2+}, \mathrm{Cu}^{2+}$, $\mathrm{Zn}^{2+}, \mathrm{Na}^{2+}, \mathrm{Mg}^{2+}$, or EDTA at $37^{\circ} \mathrm{C}$ for $30 \mathrm{~min}$. The enzyme activity of the antifungal protein was determined by the DNS method (Bailey, 1988), and the activity of the enzyme in the absence of metal cations was taken to be $100 \%$.

\section{Substrate specificity}

Different substrate solutions ( $1 \% \mathrm{w} / \mathrm{v})$ were prepared by dissolving the appropriate amount of substrate (oat glucanase, lichenan, carboxymethyl cellulose (CMC), xylan (from birch wood), laminarin, mannan, and soluble starch) in $50 \mathrm{mM}$ phosphate buffer, $\mathrm{pH}$ 6.4. Substrate specificity of the antifungal proteins was determined by measuring the enzyme activity according to the DNS method (Bailey, 1988).

\section{Kinetic parameters}

In terms of enzyme kinetic parameters, $V_{\max }$ value is the maximum rate of the enzyme at 
maximum substrate concentrations and $\mathrm{K}_{\mathrm{m}}$ is the substrate concentration at which the reaction rate is half of $\mathrm{V}_{\max }$. The $\mathrm{K}_{\mathrm{m}}$ and $\mathrm{V}_{\max }$ of the purified protein were obtained by measuring enzyme activity with the substrate oat glucan at concentrations ranging from 0.5 to $5 \mathrm{mg} / \mathrm{mL}$. The values for $\mathrm{K}_{\mathrm{m}}$ and $\mathrm{V}_{\max }$ of the proteins were determined according to the Lineweaver-Burk method.

\section{RESULTS}

\section{Purification and characterization of an antifungal protein from B. subtilis Em7}

\section{Purification of the antifungal protein}

The summary of the purification of an antifungal protein from B. subtilis Em7 is presented in Table 1. From $5000 \mathrm{~mL}$ bacterial supernatant, $1171.85 \mathrm{mg}$ total protein was obtained. After precipitating with ammonium sulfate and purification with hydrophobic chromatography and gel filtration chromatography, the active protein was purified with a yield of $0.29 \%$. Protein purification processes are shown in Figures $1 \mathrm{~A}$ and $2 \mathrm{~A}$ and detection of antifungal activities are shown in Figures 1B and 2B. The purified protein showed a single band on PAGE (Figure 2C; peak P3-2).

Table 1. Protein yield of each purification step.
\begin{tabular}{lccc}
\hline Purification step & Volume $(\mathrm{mL})$ & Total protein $(\mathrm{mg})$ & Recovery $(\%)$ \\
\hline Culture filtrate & 5000 & 1171.85 & 100 \\
Crude protein & 97.77 & 70.898 & 6.05 \\
Phenyl-Sepharose & 30 & 6.048 & 0.52 \\
Gel chromatography & 15 & 3.422 & 0.29 \\
\hline
\end{tabular}

A

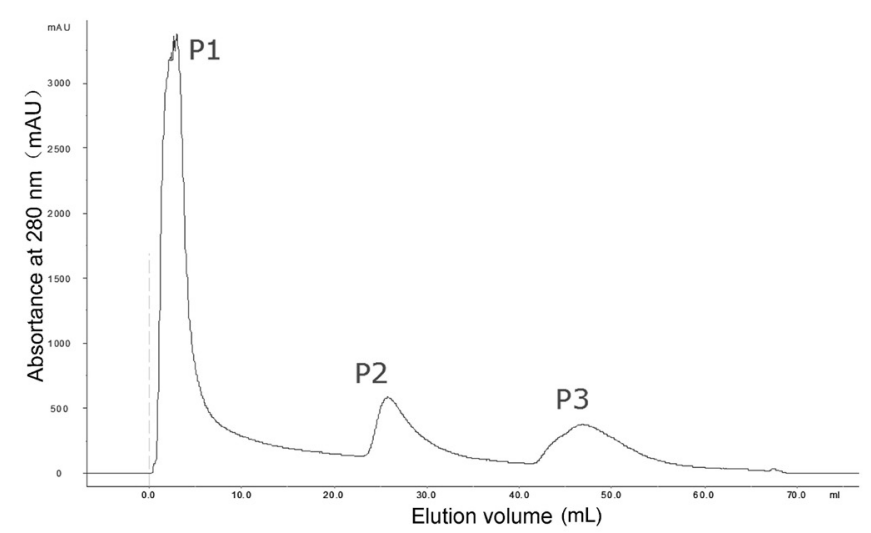

$\mathrm{B}$

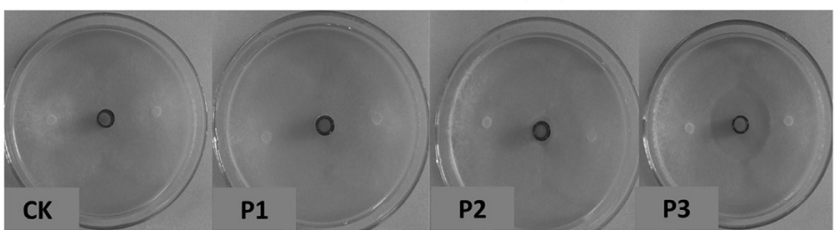

Figure 1. Separation of crude protein extract from Bacillus subtilis Em7. A. Absorbance peaks of crude proteins separated by HIC on Phenyl Sepharose. B. Inhibition of Sclerotinia sclerotiorum growth with the fractions collected from the absorption peaks (P1, P2, and P3) of crude proteins from B. subtilis Em7 by HIC on Phenyl Sepharose. CK: 


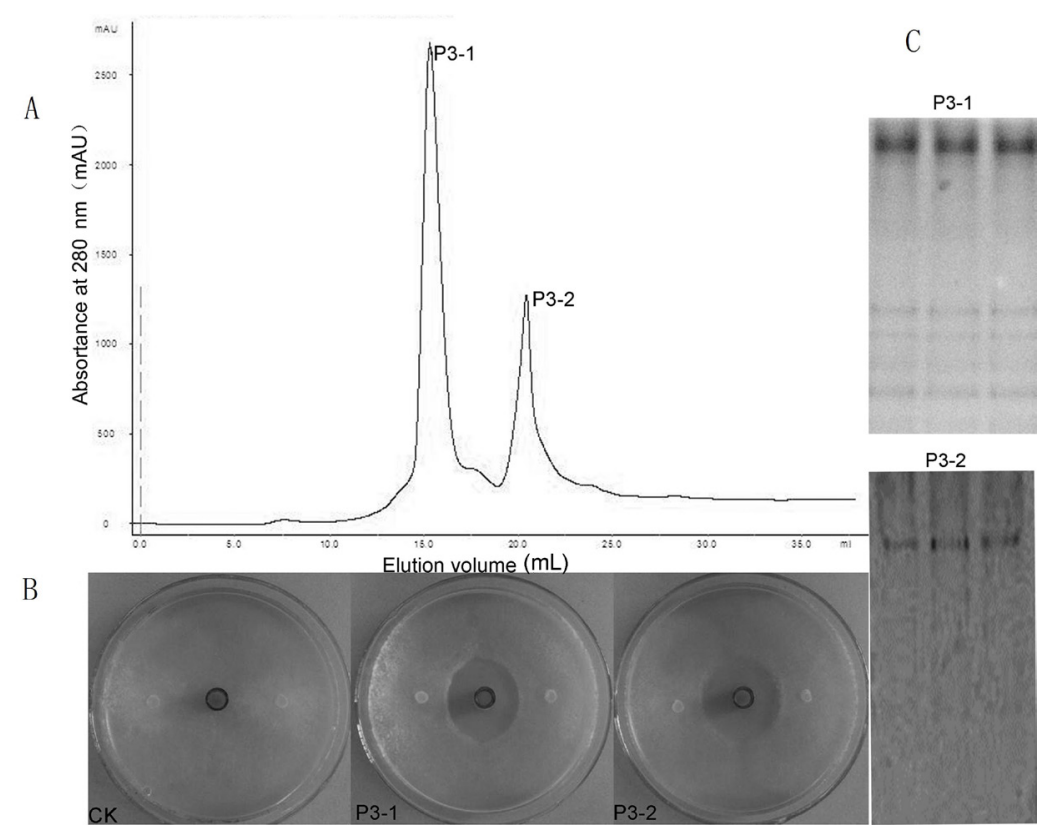

Figure 2. Purification and visualization of crude protein peak $\mathrm{P} 3$ from Bacillus subtilis $\mathrm{Em} 7$ by gel filtration chromatography and PAGE. A. Absorbance peaks of crude protein fraction P3 by gel filtration chromatography. B. Inhibition of Sclerotinia sclerotiorum growth with the fractions P3-1 and P3-2 collected from gel filtration chromatography. C. PAGE detection of the proteins from fractions P3-1 and P3-2. CK: PBS buffer.

\section{Characterization of the purified antifungal protein}

The amino acid sequence of the resulting peptides was obtained by de novo amino acid analysis using a Q-TOF2: HTATSQIPTNPGK, ANNVSMTSSGEMR, SVQTYGYGLYEVR, VQFNYYTNGAGNHEK, and NTGIVSSFFTYTGPTDGTPWDEIDIEFLGK. After the sequences were blasted on the NCBI databank, the results showed that the amino acid sequences of the five peptides exhibit a high degree of similarity with those from B. subtilis $(99 \%$, GenBank accession No. HQ834722.1), Bacillus licheniformis (98\%, GenBank accession No. AF546871.1), and Bacillus amyloliquefaciens (99\%, GenBank accession No. HG328253.1). Therefore, the protein that we obtained was identified as an antifungal protein and the deduced theoretical molecular weight of the protein was $27,586.15 \mathrm{Da}$ according to the amino acid sequence blasted on NCBI.

\section{Heterologous expression of the antifungal protein from B. subtilis Em7 in E. coli BL21}

\section{Cloning of the antifungal protein gene and sequence analysis}

The antifungal protein gene was cloned from $B$. subtilis $\mathrm{Em} 7$ and the DNA fragment of the 744-bp PCR product, encoding for 269 amino acids, was sequenced (Figure 3A). Its molecular weight is $27.9 \mathrm{kDa}$ and the theoretical isoelectric point is predicted to be 6.35 . The cloned antifungal protein gene sequence showed $99 \%$ similarity with the $\beta-1,3-1,4-$ glucanase gene of $B$. subtilis (GenBank accession No. HQ834722.1). The nucleic acid sequence of the cloned fragment was 
translated into an amino acid sequence and then predicted by protein BLAST. The result showed that the fragment cloned retained the entire region of glucanase activity.

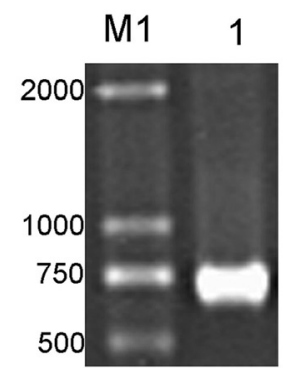

A

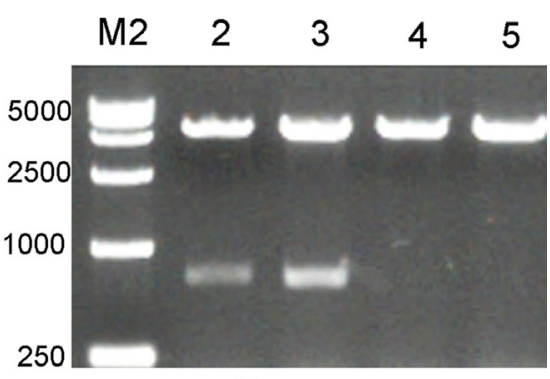

$\mathrm{B}$

Figure 3. Construction of antifungal protein gene expression vector. A. PCR amplification of antifungal protein gene. B. Agarose gel analysis of the double-digestion of the recombinant plasmid pET32a-Glu. Lanes M1, M2 = DNA molecular weight markers; lane $1=\mathrm{PCR}$ product of antifungal protein gene; lanes 2 and $3=\mathrm{pET} 32 \mathrm{a}-\mathrm{Glu}$; lanes 4 and $5=\mathrm{pET} 32 \mathrm{a}$.

\section{Expression, purification and antifungal activity detection of the recombinant protein in E. coli BL21 (DE3)}

The antifungal protein gene was successfully cloned into pET32a (+) (Figure 3B) and expressed in E. coli BL21 (DE3). Following induction with $1 \mathrm{mM} \mathrm{IPTG}$ after $36 \mathrm{~h}$ in culture at $16^{\circ} \mathrm{C}$, the enzyme activity of the recombinant protein in the supernatant reached $26,247.4 \mathrm{U} / \mathrm{mL}$, which was 35.9-fold that of the native protein in the same culture conditions.

SDS-PAGE revealed that the recombinant protein was the major protein in the supernatant of the cell lysate, with a molecular weight of approximately $48 \mathrm{kDa}$, which most likely corresponded to the $20 \mathrm{kDa}$ of Trx·Tag/His·Tag/S.Tag sequences fused to the expected $28 \mathrm{kDa} \beta-1,3-1,4-$ glucanase gene product (Figure 4). There was no recombinant protein found in the negative control, E. coli BL21 (DE3)/pET32a-Glu without IPTG induction, and the blank control, E. coli BL21 (DE3)/pET32a with IPTG induction. The purified recombinant protein showed a single band with a molecular mass of $48.0 \mathrm{kDa}$ on SDS-PAGE (Figure 5) and its antifungal activity is shown in Figure 6.

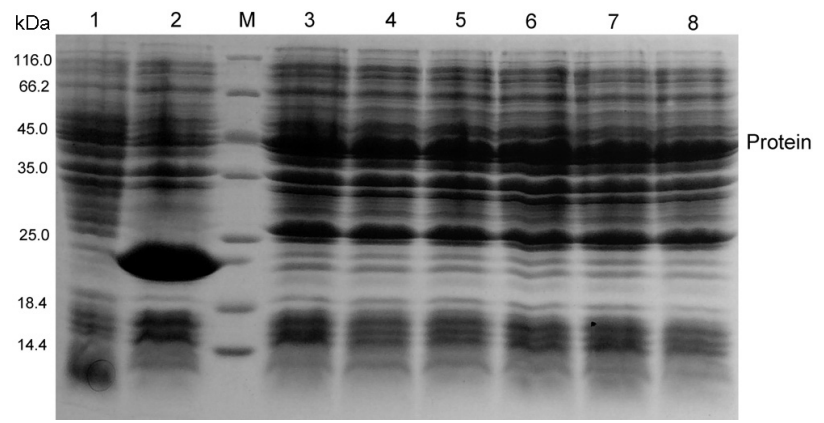

Figure 4. SDS-PAGE analysis of recombinant protein from Escherichia coli BL21 (DE3) transformed with pET32a-Glu. Lane $M=$ protein molecular weight marker; lane 1 = supernatant of the cell lysate from E. coli BL21 (DE3)/pET32a with $1 \mathrm{mM}$ IPTG induction; lane 2 = supernatant of the cell lysate from $E$. coli BL21 (DE3)/pET32a-Glu without IPTG induction; lanes 3, 4, 5, 6, 7, 8 = supernatant of the cell lysate from E. coli BL21 (DE3)/pET32a-Glu with 0.5, 1, 2, 4, 6, or 8 mM IPTG induction, respectively. 


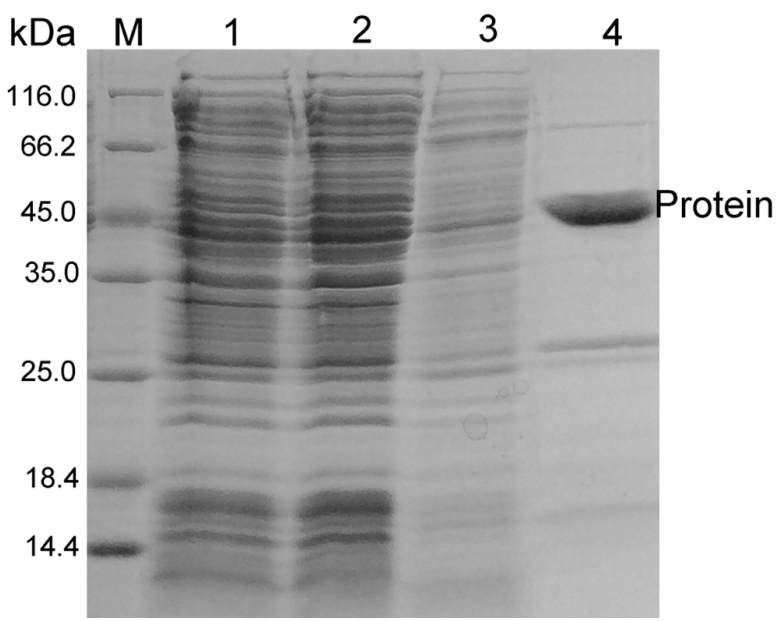

Figure 5. SDS-PAGE (15\%) of purified recombinant protein. Lane $M=$ protein molecular weight marker; lane $1=$ supernatant after sonication of Escherichia coli BL21 (DE3)/pET32a-Glu after induction with $1 \mathrm{mM}$ IPTG; lane $2=$ supernatant loaded onto the affinity column; lane $3=$ wash from affinity purification; lane $4=$ affinity purified protein (-His tag) after $50 \mathrm{mM}$ imidazole elution.

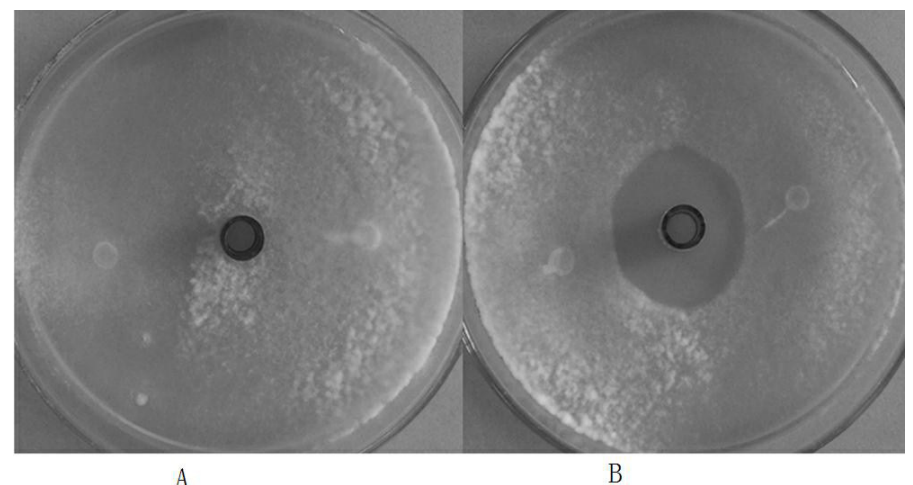

Figure 6. Inhibition of Sclerotinia sclerotiorum growth with purified recombinant protein. A. Inhibition of S. sclerotiorum growth with PBS buffer as a control (CK). B. Inhibition of S. sclerotiorum with purified recombinant protein.

\section{Enzyme characterization and comparison of the native antifungal protein from B. subtilis Em7 and the recombinant protein from E. coli BL21}

\section{Effect of $\mathrm{pH}$ on enzymatic activity and stability of the purified protein}

For both the native and recombinant proteins, the enzyme activity was relatively stable between $\mathrm{pH} 5.0$ and 8.6 and the enzyme activity was the highest when the proteins were incubated in buffer at $\mathrm{pH}$ 6.0. When the buffer $\mathrm{pH}$ was lower than 5.0 or higher than 9.0 , both the activity and stability of the protein decreased. When the buffer $\mathrm{pH}$ was 4.4 or 9.0 , the enzyme activity of the native protein decreased to 46.32 and $26.48 \%$, respectively, while for the recombinant protein, the results were 43.98 and $21.15 \%$, respectively (Figure $7 \mathrm{~A}$ ). When the protein was incubated in 
buffers at $\mathrm{pH} 4.4$ or 9.0 for $2 \mathrm{~h}$ at $37^{\circ} \mathrm{C}$, the remaining enzyme activity was 26.98 and $33.63 \%$ for the native protein, respectively, and 33.65 and $25.97 \%$ for the recombinant protein, respectively (Figure 7A).
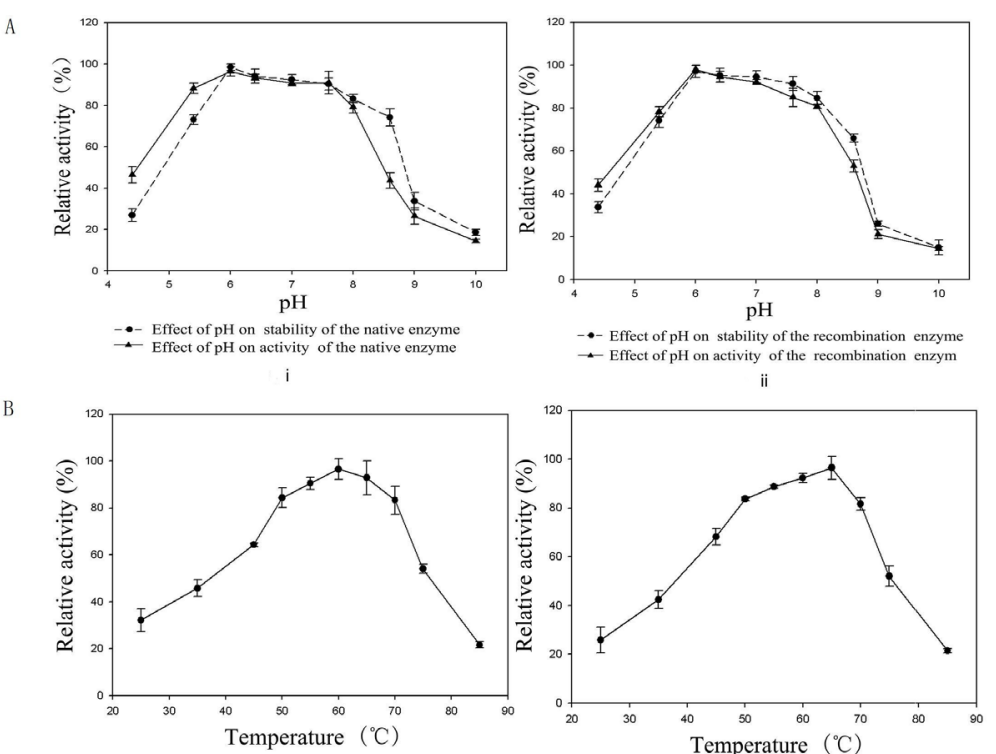

C
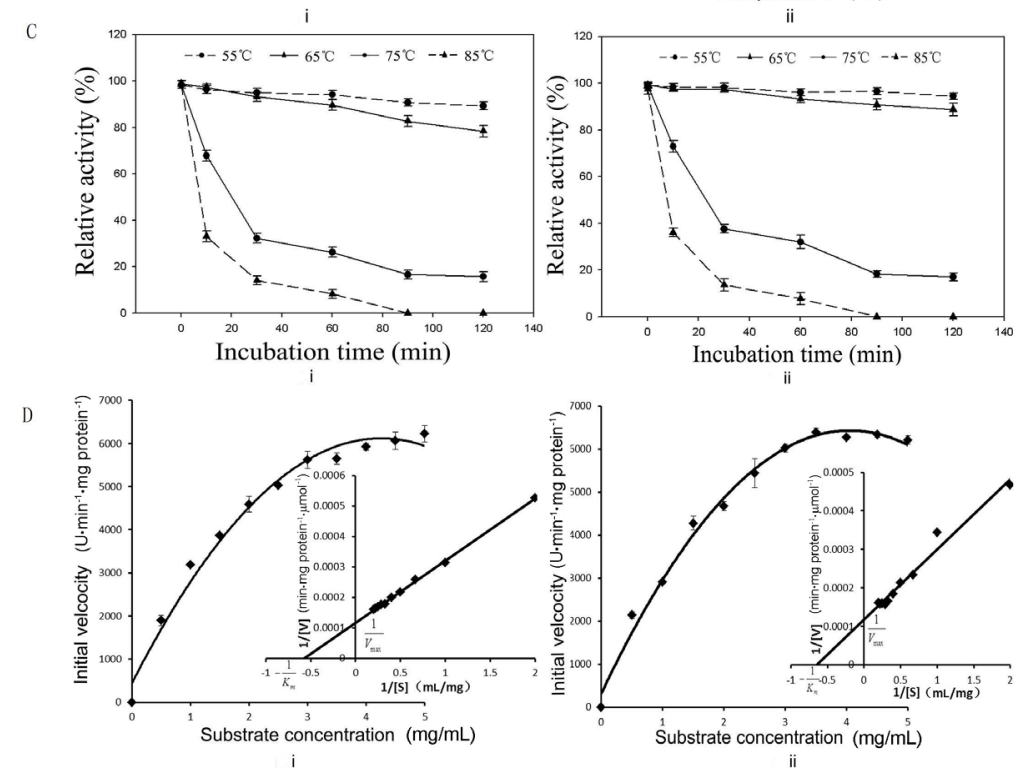

Figure 7. Comparison of native and recombinant protein from Bacillus subtilis Em7 and Escherichia coli BL21, respectively. Results are reported as means $\pm \mathrm{SD}(\mathrm{N}=3)$. A. Effect of $\mathrm{pH}$ on the activity and stability of the native i) and recombinant ii) protein. B. Effect of temperature on the activity of the native i) and recombinant ii) protein. C. Effect of temperature on the stability of the native i) and recombinant ii) protein. $\mathbf{D}$. Effect of substrate concentration on the $\beta-1,3-1,4-$ glucanase activity of the native i) and recombinant ii) protein. The inset shows the Lineweaver-Burk plot of initial velocity versus various fixed oat $\beta$-glucan concentrations. 


\section{Effect of temperature on enzyme activity and stability of the purified protein}

In order to determine the effect of temperature on the purified protein, enzyme activity was estimated at different temperatures ranging from $25^{\circ}$ to $85^{\circ} \mathrm{C}$. The optimal temperature of the native and recombinant protein was $60^{\circ}$ and $65^{\circ} \mathrm{C}$, respectively (Figure $7 \mathrm{~B}$ ). In the thermostability assay, the native protein was stable at $65^{\circ} \mathrm{C}$ and retained more than $82.7 \%$ of its activity when incubated at $65^{\circ} \mathrm{C}$ for $1.5 \mathrm{~h}$ while the recombinant protein retained $90.77 \%$ of its activity under the same treatment. For the native protein, it retained 67.83 and $33 \%$ activity after incubation at $75^{\circ}$ and $85^{\circ} \mathrm{C}$ for $10 \mathrm{~min}$, respectively, while the recombinant protein retained 72.88 and $36.07 \%$ of its activity at the same temperatures, respectively (Figure 7C).

\section{Effect of metal ions on the purified protein}

The enzyme activity of the protein was measured after adding $5 \mathrm{mM}$ of different metal ions to phosphate buffer $\left(50 \mathrm{mM}, \mathrm{pH}\right.$ 6.4) (Table 2). The test results showed that $\mathrm{Co}^{2+}, \mathrm{Fe}^{2+}$ and $\mathrm{Mg}^{2+}$ significantly increased the activity of both the native and recombinant protein, with the maximum rate increasing by almost $26 \%$ by addition of $\mathrm{Fe}^{2+}$ to the native protein. The addition of $\mathrm{Ca}^{2+}$ enhanced the activity of the native protein to $107 \%$ and about the recombinant protein to $109 \%$. The addition of $\mathrm{Na}^{+}$slightly inhibited the activity of the native protein but had no effect on the recombinant protein. The addition of $\mathrm{K}^{+}$enhanced activity of the recombinant protein to $107 \%$ and the native protein to $102 \%$. Conversely, both the native and recombinant protein were inactivated by $\mathrm{Zn}^{2+}, \mathrm{Cu}^{2+}$, and EDTA, and the maximum inhibition rate was approximately $77 \%$.

\begin{tabular}{|c|c|c|}
\hline \multirow[t]{2}{*}{ Metal ion or chemicals } & \multicolumn{2}{|c|}{ Relative activity (\%) ${ }^{\mathrm{a}}$} \\
\hline & Native & Recombinant \\
\hline $\mathrm{Cu}^{2+}$ & $81.32 \pm 8.62$ & $78.06 \pm 6.64$ \\
\hline $\mathrm{Zn}^{2+}$ & $80.48 \pm 2.988$ & $77.59 \pm 3.17$ \\
\hline $\mathrm{Mg}^{2+}$ & $112.688 \pm 7.98$ & $115.52 \pm 12.57$ \\
\hline $\mathrm{Mn}^{2+}$ & $109.35 \pm 4.86$ & $109.48 \pm 15.86$ \\
\hline $\mathrm{K}^{+}$ & $102.67 \pm 4.93$ & $107.72 \pm 5.17$ \\
\hline $\mathrm{Na}^{+}$ & $94.07 \pm 6.874$ & $101.11 \pm 7.791$ \\
\hline $\mathrm{Fe}^{2+}$ & $126.56 \pm 15.39$ & $125.05 \pm 8.85$ \\
\hline $\mathrm{Ca}^{2+}$ & $107.51 \pm 7.07$ & $109.76 \pm 7.77$ \\
\hline $\mathrm{Co}^{2+}$ & $110.09 \pm 6.29$ & $116.13 \pm 8.783$ \\
\hline EDTA & $85.61 \pm 12.25$ & $81.32 \pm 8.62$ \\
\hline
\end{tabular}

Values represent means $\pm S D(N=3)$ relative to the untreated control samples.

\section{Substrate specificity of the antifungal protein}

In order to determine the specific glycosidic linkages of the protein, multiple substrates were tested. The native and recombinant protein showed the same substrate specificity. Both were inactive against CMC, xylan, soluble starch and mannan, and showed higher hydrolytic activity on oat $\beta$-glucan than on lichenan (Table 3 ). All results indicate that the antifungal protein can

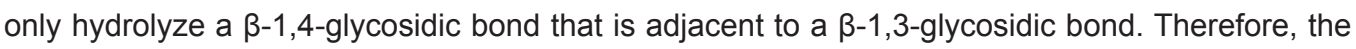
antifungal protein that we obtained was verified as a true $\beta-1,3-1,4$-glucanase. 
Table 3. Substrate specificity of native and purified recombinant protein.

\begin{tabular}{llcr}
\hline Substrate & Main linkage types & Native protein activity $(\mathrm{U} / \mathrm{mg})$ & Recombinant protein activity $(\mathrm{U} / \mathrm{mg})$ \\
\hline Oat glucan & $\beta-1,3$ and $\beta-1,4$ & $647 \pm 21$ & $26247.4 \pm 272$ \\
Lichenan & $\beta-1,3$ and $\beta-1,4$ & $187 \pm 17$ & $7445 \pm 448$ \\
Carboxymethyl cellulose sodium & $\beta-1,4$ & - & - \\
Xylan from birch & $\beta-1,4$ & - & - \\
Soluble starch & $\alpha-1,4$ and $\alpha-1,6$ & - & - \\
Mannan & $\alpha-1,6$ & - & -
\end{tabular}

(-) Activity not detected. Enzyme activity is reported as means \pm SD. All assays were performed in triplicate.

\section{Kinetic parameters of the purified protein}

Hyperbolic saturation curves and the corresponding Lineweaver-Burk curves were obtained by measuring the activity of the protein at different concentrations of substrate (oat $\beta$-glucan) (Figure 7D). The estimated $\mathrm{K}_{\mathrm{m}}$ of the native and recombinant protein was 1.71 and $1.53 \mathrm{mg} / \mathrm{mL}$, respectively. The $\mathrm{V}_{\max }$ values were 8333.33 and $8715.2 \mathrm{U} \cdot \mathrm{min}^{-1} \cdot \mathrm{mg} \mathrm{protein}^{-1}$ for the native and recombinant proteins, respectively. For the native protein, the catalytic constant and the specificity constant values were $1666.67 / \mathrm{s}$ and $974.66 \mathrm{~mL} \cdot \mathrm{s}^{-1} \cdot \mathrm{mg}^{-1}$, respectively. For the recombinant protein, the same values were $1743.04 / \mathrm{s}$ and $1139.24 \mathrm{~mL} \cdot \mathrm{s}^{-1} \cdot \mathrm{mg}^{-1}$, respectively.

In summary, all of our results showed that the recombinant and native proteins were almost identical in enzymatic activity, except that the recombinant protein exhibited higher activity than the native protein. In addition, the properties of the proteins showed that they exhibit high thermostability, acid resistance and a stricter preference for oat $\beta$-glucan than has been previously reported for $\beta-1,3-1,4-$ glucanases isolated from $B$. subtilis, which is particularly true for the recombinant protein.

\section{DISCUSSION}

In recent years, Bacillus species of bacteria have been examined for controlling the development of soil-borne diseases. B. subtilis as a biocontrol agent has many advantages, including production of heat-resistant spores, which is convenient for preparation and storage (Emmert and Handelsman, 1999). Furthermore, B. subtilis can produce a variety of antifungal agents, including volatiles (Fiddaman and Rossall, 1993), lipopeptides (Touré et al., 2004; Stein, 2005), and several modified small peptides and proteins (Liu et al., 2007). These antifungal agents showed species diversity and strong antagonistic capacity.

In a preliminary study, our results using light microscopy and scanning electron microscopy studies showed that $B$. subtilis $\mathrm{Em} 7$ severely affected hyphal growth of $S$. sclerotiorum, causing leakage and exudate accumulation in the region of the hyphal tips in vitro (Gao et al., 2014). Further studies showed that the culture filtrate of $B$. subtilis Em7 can inhibit the mycelium growth of $S$. sclerotiorum, and antimicrobial proteins may be the main antifungal agents. The antifungal proteins were divided into two groups: one is precipitated by $30 \%$ ammonium sulfate and the other is precipitated with between 30 and $60 \%$ ammonium sulfate. The antifungal protein P3-2 (Figure 2) was purified and identified as a $\beta-1,3-1,4$-glucanase.

The main component of the fungal cell wall is $\beta$-glucan (Bom et al., 1998), which can be degraded by $\beta-1,3-1,4-$ glucanases. Therefore, $\beta-1,3-1,4-$ glucanase should display antifungal activity on plant pathogens. However, the antifungal activity of $\beta-1,3-1,4$-glucanase has attracted 
very limited interest (Liu, 2007). Although $\beta-1,3-1,4-$ glucanases exhibited activity on fungal hyphae, the difference was not significant. Our results showed that proteins P3-1 and P3-2 (Figure 2) exhibited almost the same antifungal activity at the same protein concentration. The results of PAGE showed that protein P3-1 is a mixture that needs further purification and protein P3-2 was identified as $\beta-1,3-1,4-$ glucanase. This shows that $\beta-1,3-1,4-$ glucanase has very strong antifungal activity on $S$. sclerotiorum, and it may be one of the main active antifungal substances of $B$. subtilis Em7. In subsequent studies, the antifungal spectrum of the protein identified in P3-2 will be tested using other plant pathogenic fungi such as Fusarium graminearum, Rhizoctonia cerealis, Fusarium oxysporum, Botrytis cinerea, and Gaeumannomyces graminis var. tritici. At the same time, the antifungal mechanism of the protein P3-2 will also be examined.

In addition, $\beta-1,3-1,4-$ glucanase is an important industrial enzyme, and has widely been used in the brewing and animal feed additive industry. However the $\beta-1,3-1,4$ glucan was usually inactivated under the high temperature and low pH conditions. Therefore, thermostability, acid tolerance and high activity are often the main research goals for improving the characteristics of an enzyme. Our results showed that the optimal temperature for the recombinant protein was $60^{\circ}$ and $65^{\circ} \mathrm{C}$ for the native protein. There was no significant differences between the native and the recombinant proteins. The recombinant protein exhibited maximal enzyme activity at $65^{\circ} \mathrm{C}$ with oat $\beta$-glucan as substrate, and showed a higher thermoresistance than previously reported for $\beta-1,3-1,4-$ glucanases, such as from $B$. subtilis MA139 $\left(40^{\circ} \mathrm{C}\right)$ (Qiao et al., 2009), B. licheniformis EGW039 $\left(40^{\circ} \mathrm{C}\right)$ (Teng et al., 2006), B. amyloliquefaciens ATCC $23350\left(50^{\circ} \mathrm{C}\right)$ (Sun et al., 2012), and thermophilic Rhizomucor miehei $\left(60^{\circ} \mathrm{C}\right)$ (Tang et al., 2012). For the thermostability assay, the native and recombinant proteins were stable at $65^{\circ} \mathrm{C}$ for $1.5 \mathrm{~h}$ and had residual activity of 82.7 and $90.77 \%$, respectively. For the native protein, it retained 67.83 and $33 \%$ of its activity after incubation at $75^{\circ}$ and $85^{\circ} \mathrm{C}$ for $10 \mathrm{~min}$, respectively, while for the recombinant protein the result was 72.88 and $42.36 \%$, respectively, which is higher than that of $\beta-1,3-1,4$-glucanases obtained from B. amyloliquefaciens $\left(50 \%, 4 \mathrm{~min}\right.$ at $\left.70^{\circ} \mathrm{C}\right)$ (Hofemeisrer et al., 2003), B. subtilis MA139 $(10 \%, 5$ min at $70^{\circ} \mathrm{C}$ ) (Qiao et al., 2009), and B. licheniformis EGW039 $\left(50 \%, 10 \mathrm{~min}\right.$ at $70^{\circ} \mathrm{C}$ ) (Teng et al., 2006). The high thermal stability of the protein may be related to its structure.

Both the native and recombinant proteins were active and relatively stable between $\mathrm{pH} 5.0$ and 8.6. When the protein was incubated in buffer at $\mathrm{pH} 4.4$ for $2 \mathrm{~h}$ at $37^{\circ} \mathrm{C}$, the retaining enzyme activity was $66.32 \%$ for the native protein and $63.98 \%$ for the recombinant protein. In addition, the native and recombinant proteins from this study showed stronger acid tolerance than $\beta-1,3-1,4-$ glucanases previously reported (Wen et al., 2005).

The native and recombinant protein exhibited a strict preference for oat $\beta$-glucan and lichenan, and the maximum activity of the recombinant protein reached up to $26,247.4 \mathrm{U} / \mathrm{mg}$, which is higher than those ever reported for a $\beta-1,3-1,4-g l u c a n a s e$ from a Bacillus strain. The yield of natural $\beta$-glucanase from Bacillus species is usually very low, owing the production of the enzyme only to meet the needs of the species to survive. The $E$. coli expression system is currently the most widely used system and allows for the expression of the target protein by different strategies. For example, in order to increase the solubility of recombinant proteins, GST fusion (and other fusion tags) and secretory expression systems have been developed. In addition, another notable feature of $E$. coli is the high growth rate, efficient production, and easy directional transformation of enzyme protein molecules. Therefore, in our previous studies, three kinds of expression plasmids [pEGX$4 \mathrm{~T}-1, \mathrm{pET} 28 \mathrm{a}(+)$ and $\mathrm{pET} 32 \mathrm{a}(+)$ ] were used for the cloning and expression of the $\beta$-glucanase produced by $B$. subtilis Em7 by our laboratory. Teng et al. (2006) reported that the recombinant 
plasmid pET28a (+)-bgl with the T7 promoter under the control of Lacl can effectively reduce the toxicity of basal expression for the host bacteria and effectively increase the expression level of the recombinant protein. However, in our previous study, the recombinant plasmid pET28a(+)-bgl was induced for expression of the target protein but we found that the control strain BL21 (DE3) also expressed the target protein. Therefore, we need to further confirm the purpose of the protein in BL21 (DE3) and determine if it is typically expressed in the recombinant strains by western blot. After we constructed the recombinant plasmid pEGX-4T-1-bgl, due to the high copy number of the plasmid in the cell, we could express GST fusion to improve the solubility of the recombinant protein. It is desirable to obtain the target protein by constructing the recombinant plasmid $p E G X$ 4T-1-bgl and then transforming it into E. coli BL21 for expression studies. The results showed that the protein has not been effectively expressed. This may be due to the fact that the Tac promoter is weaker than the T7 promoter. Prior studies have also reported that the activity of recombinant proteins expressed by pEGX-4T-1 is not high. In this study, the protein was not expressed by the recombinant plasmid pEGX-4T-1-bgl yet the reason for this is unclear. Finally, the $\beta-1,3-1,4-$ glucanase gene of $B$. subtilis $\mathrm{Em} 7$ was inserted into the vector pET32a and expressed in $E$. coli BL21 (DE3). As expected, the expression efficiency of the vector pET32a was very high for the pET system. Under the conditions of $1 \mathrm{mM} \mathrm{IPTG}, 16^{\circ} \mathrm{C}$ and $36 \mathrm{~h}$ induced in LB medium, almost all of the cells are expressing the target protein. The enzyme activities of recombinant $\beta-1,3-1,4-$ glucanase reached $26,247.4$ and $7445 \mathrm{U} / \mathrm{mL}$ for $\beta$-glucan and lichenan, respectively. Our results indicate that expression of this $\beta$-glucanase gene in the pET32a (+) plasmid in E. coli BL21 (DE3) is capable of generating very high activity. This will greatly reduce the production cost, resulting in a good potential for industrial applications.

Overall, the high activity, high thermostability and low pH tolerance make this enzyme appropriate for industrial application. Future studies will focus on the further purification of antifungal proteins from B. subtilis Em7 and their mechanism of the control of S. sclerotiorum and other plant diseases.

In conclusion, we successfully purified an antifungal protein from endophytic $B$. subtilis Em7. The protein isolated may be regarded as $\beta-1,3-1,4-$ glucanase according to amino acid sequences of five peptides. According to the DNA sequence, the antifungal protein was cloned and expressed in E. coli BL21. The purified recombinant protein was characterized to show almost the same properties to the native protein and exhibited inhibitory activity on mycelial growth of S. sclerotiorum. The experimental results showed that the $\beta-1,3-1,4-$ glucanase may play a very important role in $B$. subtilis Em7 biocontrol function. In addition, the properties of high thermostability, acid resistance and high specific activity make this enzyme a prospect for industry development and application.

\section{Conflicts of interest}

The authors declare no conflict of interest.

\section{ACKNOWLEDGMENTS}

Research supported by the Special Fund for Agro-Scientific Research in the Public Interest (\#201103016), and the "111" Project from the Education Ministry of China (\#B07049). We are grateful to Dr. Bing Liu (Jiangxi Agricultural University) for comments and improvement of the manuscript. 


\section{REFERENCES}

Bailey MJ (1988). A note on the use of dinitrosalicylic acid for determining the products of enzymatic reactions. Appl. Microbiol. Biotechnol. 29: 494-496.

Berendsen RL, Pieterse CM and Bakker PA (2012). The rhizosphere microbiome and plant health. Trends Plant Sci. 17: 478-486.

Besson F and Michel G (1990). Mycosubtilins B and C: minor antibiotics from mycosubtilin producing Bacillus subtilis. Microbios 62: 93-99.

Bol GJ and Hall R (1994). Index of plant hosts of Sclerotinia sclerotiorum. Can. J. Plant Pathol. 16: 93-108.

Bom IJ, Dielbandhoesing SK, Harvey KN, Oomes SJ, et al. (1998). A new tool for studying the molecular architecture of the fungal cell wall: one-step purification of recombinant trichoderma $\beta-(1-6)$-glucanase expressed in Pichia pastoris. Biochim. Biophys. Acta 1425: 419-424.

Bradford MM (1976). A rapid and sensitive method for the quantitation of microgram quantities of protein utilizing the principle of protein-dye binding. Anal. Biochem. 72: 248-254.

Cawoy H, Debois D, Franzil L, De Pauw E, et al. (2015). Lipopeptides as main ingredients for inhibition of fungal phytopathogens by Bacillus subtilis/amyloliquefaciens. Microb. Biotechnol. 8: 281-295.

Ebata M, Miyazaki K and Takahashi Y (1969). Studies on subsporin. I. Isolation and characterization of subsporins A, B and C. J. Antibiot. 22: 467-472.

Emmert EA and Handelsman J (1999). Biocontrol of plant disease: a (Gram-) positive perspective. FEMS Microbiol. Lett. 171: 1-9. Fiddaman PJ and Rossall S (1993). The production of antifungal volatiles by Bacillus subtilis. J. Appl. Bacteriol. 74: 119-126.

Gao X, Han Q, Chen Y, Qin H, et al. (2014). Biological control of oilseed rape sclerotinia stem rot by Bacillus subtilis strain Em7. Biocontrol Sci. Technol. 24: 39-52.

Haas D and Défago G (2005). Biological control of soil-borne pathogens by fluorescent pseudomonads. Nat. Rev. Microbiol. 3: $307-319$.

Hofemeisrer J, Kurtz A, Borriss R and Knowles J (2003). The $\beta$-glucanase gene from Bacillus amyloliquefaciens shows extensive homology with that of Bacillus subtilis. Gene 49: 177-187.

Isogai A, Takayama S, Murakoshi S and Suzuki A (1982). Structure of $\beta$-amino acids in antibiotics iturin A. Tetrahedron Lett. 23: 3065-3068.

Katz E and Demain AL (1977). The peptide antibiotics of Bacillus: chemistry, biogenesis, and possible functions. Bacteriol. Rev. 41: 449 .

Khardenavis AA, Kapley A and Purohit HJ (2007). Simultaneous nitrification and denitrification by diverse Diaphorobacter sp. Appl. Microbial. Biotechnol. 77: 403-409.

Kluge B, Vater J, Salnikow J and Eckart K (1988). Studies on the biosynthesis of surfactin, a lipopeptide antibiotic from Bacillus subtilis ATCC 21332. FEBS Lett. 231: 107-110.

Korzybski T, Kowszyk-Gindifer Z and Kurylowicz W (1978). Antibiotics: origin, nature and properties. Am. Soc. Microbiol. 3 : 1529-1661.

Kugler M, Loeffler W, Rapp C, Kern A, et al. (1990). An antifungal phosphono-oligopeptide of Bacillus subtilis ATCC 6633: biological properties. Arch. Microbiol. 153: 276-281.

Liu Y, Chen Z, Ng TB, Zhang J, et al. (2007). Bacisubin, an antifungal protein with ribonuclease and hemagglutinating activities from Bacillus subtilis strain B-916. Peptides 28: 553-559.

Liu YL (2007). Antimicrobial activity synergism between Bacillus lytic enzyme L27 and beta-1,3-1,4-glucanase. Southwest University, Chongqing, 10-14.

Majumdar SK and Bose SK (1958). Mycobacillin, a new antifungal antibiotic produced by B. subtilis. Nature 181: 134-135.

Mizumoto K and Sawa H (2007). Two $\beta$ s or not two $\beta$ s: regulation of asymmetric divisions by $\beta$-catenin. Trends Cell. Biol. 17: 465-473.

Oilcrop Research Institute, Chinese Academy of Sciences (1975). Sclerotinia disease of oilseed crops. Agriculture Press, Beijing.

Peypoux F, Besson F, Michel G and Delcambe L (1981). Structure of bacillomycin D, a new antibiotic of the iturin group. Eur. J. Biochem. 118: 323-327.

Peypoux F, Pommier MT, Das BC, Besson F, et al. (1984). Structures of bacillomycin D and bacillomycin L peptidolipid antibiotics from Bacillus subtilis. J. Antibiot. 37: 1600-1604.

Peypoux F, Pommier MT, Marion D, Ptak M, et al. (1986). Revised structure of mycosubtilin, a peptidolipid antibiotic from Bacillus subtilis. J. Antibiot. 39: 636-641.

Qiao J, Dong B, Li Y, Zhang B, et al. (2009). Cloning of a beta-1,3-1,4-glucanase gene from Bacillus subtilis MA139 and its functional expression in Escherichia coli. Appl. Biochem. Biotechnol. 152: 334-342.

Sadfi N, Cherif M, Fliss I, Boudabbous A, et al. (2001). Evaluation of bacterial isolates from salty soils and Bacillus thuringiensis 
strains for the biocontrol of Fusarium dry rot of potato tubers. J. Plant Pathol. 83: 101-117.

Sengupta S, Banerjee AB and Bose SK (1971). Gamma-glutamyl and D- or L-peptide linkages in mycobacillin, a cyclic peptide antibiotic. Biochem. J. 121: 839-846.

Stein T (2005). Bacillus subtilis antibiotics: structures, syntheses and specific functions. Mol. Microbiol. 56: 845-857.

Sun JT, Wang HX, Lv WP, Ma CY, et al. (2012). Cloning and expression of a thermostable $\beta-1,3-1,4$-glucanase from Bacillus amyloliquefaciens ATCC 23350. Ann. Microbiol. 62: 1235-1242.

Tang Y, Yang S, Yan Q, Zhou P, et al. (2012). Purification and characterization of a novel beta-1,3-1,4-glucanase (lichenase) from thermophilic Rhizomucor miehei with high specific activity and its gene sequence. J. Agr. Food Chem. 60: $2354-2361$.

Teng D, Wang JH, Fan Y, Yang YL, et al. (2006). Cloning of $\beta-1,3-1,4-$ glucanase gene from Bacillus licheniformis EGW039 (CGMCC 0635) and its expression in Escherichia coli BL21 (DE3). Appl. Microbiol. Biotechnol. 72: 705-712.

Touré Y, Ongena M, Jacques P, Guiro A, et al. (2004). Role of lipopeptides produced by Bacillus subtilis GA1 in the reduction of grey mould disease caused by Botrytis cinerea on apple. J. Appl. Microbiol. 96: 1151-1160.

Tsuda K, Kosaka Y, Tsuge S, Yasuyuki K, et al. (2001). Evaluation of the endophyte Enterobacter cloacae SM10 isolated from spinach roots for biological control against Fusarium wilt of spinach. J. Gen. Plant Pathol. 67: 78-84.

Wen FY and Liao FP (2010). Cloning, expression and application of $\beta-1,3-1,4-$ glucanase gene from Paenibaccillus polymyxa CP7. Sci. Agric. Sin. 43: 4614-4623.

Wen TN, Chen JL, Lee SH, Yang NS, et al. (2005). A truncated Fibrobacter succinogenes 1,3-1,4- $\beta$-D-glucanase with improved enzymatic activity and thermotolerance. Biochemistry 44: 9197-9205.

Zhang XL, Sun XM and Zhang GF (2003). Preliminary report on the monitoring of the resistance of Sclerotinia sclerotiorum to carbendazim and its internal management. Nongyao Kexue Yu Guanli 24: 18-22. 